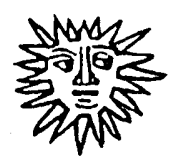

\title{
POOR MAXI'S WINDMILL: AQUATIC SYMBOLISM IN FORTUNATA Y JACINTA*
}

T the not-so-distant past it was sufficient merely to tell students 1 in a Galdós seminar that Maxi Rubín and Fortunata in Fortunata y Jacinta were obviously mismated and that their marriage was doomed to failure. I have found, however, that today's lessinhibited student frequently exhibits a curiosity bordering on the morbid about the details of Maxi's fiasco. Is there, perhaps, a specific sexual dysfunction, one that might be susceptible to treatment through therapeutic techniques-such as those of Masters and Johnson-about which American students have now read so much? Further, students ask just how realistic was Spain's most famous realist when it came to discussing the sexual basis of marriage in Fortunata y Jacinta.

In responding to these concerns, I have discovered what I consider to be a significant symbolic pattern in the narrative fabric of Fortunata y Jacinta, by means of which Galdós conveys to the reader the precise nature of Maxi and Fortunata's marital problem. The remainder of this study will deal with the theme and its variations which Galdós develops relating to the key element of the pattern-a subject much on the minds of nineteenth-century madrileños: water and its transmission.

Fortunata y Jacinta was written at a time when water had become generally and easily available for the first time in Madrid as a result of municipal projects energetically supported by Bravo Murillo ("Ministro de Fomentos") and the Marqués de Pontejos

* I wish to express my appreciation to the General Research Fund Committee of the University of Kansas for help in making this study possible. 
(Mayor of Madrid). This revolutionary development, in which water from the Lozoya River was obtained, stored, and distributed, clearly captured Galdós' imagination, for as early as Chapter ii he mentions the changing water supply in his characterization of Isabel Cordero de Arnaiz. The latter saved the family business, in part, by having "presentido el Canal de Lozoya." She "presintió la traída de aguas de Lozoya," in an era when during the hot summers,

el Ayuntamiento [todavía] refrescaba y alimentaba las fuentes del Berro y de la Teja con cubas de agua sacada de los pozos; en aquellos tiempos en que los portales eran sentinas y en que los vecinos iban de un cuarto a otro con el pucherito en la mano, pidiendo por favor un poco de agua para afeitarse.

La perspicaz mujer vio el porvenir, oyó hablar del gran proyecto de Bravo Murillo, como de una cosa que ella había sentido en su alma. Por fin Madrid, dentro de algunos años, iba a tener raudales de agua distribuidos en las calles y plazas, y adquiriría la costumbre de lavarse, por lo menos, la cara y las manos. Lavadas estas partes, se lavaría después otras. Este Madrid, que entonces era futuro, se le presentó con visiones de camisas limpias en todas las clases, de mujeres ya acostumbradas a mudarse todos los días, y de señores que eran la misma pulcritud. De aquí nació la idea de dedicar la casa al género blanco.

(p. 133)

Galdós subsequently lists the completion of the municipal water system as one of the most important events of Isabel II's reign and he has Isabel Cordero de Arnaiz recall that one of her children was born "el día de San Juan del 58, el mismo día que se inauguró la traída de aguas" (p. 134). ${ }^{2}$

In Book II when Galdós is ready for Maxi to begin his amorous

${ }^{1}$ Benito Pérez Galdós, Fortunata y Jacinta, ed. Pedro Ortiz Armengol (Madrid, 1979), p. 134. All subsequent references are to this edition and will be noted in the text of this study.

${ }^{2}$ In his column for La Prensa of Buenos Aires, Galdós wrote in more detail concerning the bringing of the water from the Lozoya River. He says, "Antes de la redención del mundo, es decir, antes de la traída de aguas, obra humanitaria que debemos a Bravo Murillo . . . para lavarse costaba un ojo de la cara, se mascaba el polvo en las calles, que no conocían el riego. No había más paseos que el Retiro y el Prado, y el primero, perteneciente a la Casa Real, estaba en su mayor parte cerrado al público . . . Del año 60 acá o del 58 . . . han cambiado radicalmente las cosas. Raudales de agua purísima y de superior calidad se distribuyen por todas las casas, suben a todos los pisos, refrescan la atmósfera, alimentan espléndida vegetación. Madrid se ha transformado" (William H. Shoemaker, Las cartas desconocidas de Galdós en "La Prensa" de Buenos Aires [Madrid, 1973], pp. 468-69). 
adventures (at age 25), he has Maxi and his aunt change neighborhoods. They move from Salamanca to Chamberi, the latter being south of the Canal de Isabel II and close to the Depósito de Lozoya and the Depósito del Canal de Isabel II. ${ }^{3}$ Galdós thus purposefully locates much of the action of the second volume at the northern edge of the city, out by the municipal waterworks, and it is in this neighborhood of abundant water that Maxi meets Fortunata.

Having established the abundance and availability of water in the historical context, Galdós has prepared the ground for his symbolic use of the same substance. On the most literal level, the presence of water suggests the gratification of sexual desire, and its relative quantity becomes an important clue in interpretation. In Volume II of Fortunata y Jacinta, strategically-placed references to water abound. Before Fortunata enters the Micaelas Convent, she and Maxi take a walk along the northern edge of Madrid and stop at the "depósitos de agua," and see "detrás de Madrid un horizonte inmenso que parecía la mar" (p. 439). Upon entering the convent, Fortunata discovers that it is very close to "el depósito de Aguas de Lozoya" (p. 462), and that on the very convent grounds there is a windmill whose energy serves to pump water through a pipe to the convent. It would appear that the ardent and fertile Fortunata should have access to all the water she might need. However, this does not turn out to be the case. In order to understand why, it is helpful to note that Galdós clearly and repeatedly associates Fortunata's future husband with the convent windmill. ${ }^{4}$

3 The Depósito del Canal de Lozoya is located at Bravo Murillo 30 y 41 and Santa Engracia 117, while the Depósito del Canal de Isabel II is at Bravo Murillo 34. The former was constructed in 1858 and the latter was started in 1874, and was being constructed during the fictional time of Fortunata $y$ Jacinta. It has "una bóveda de $207 \mathrm{~m}$. de largo por 137 de ancho, y reposa sobre 1.040 pilares de granito, con una capacidad de $180.000 \mathrm{~m}^{3}$ " ("Madrid," Enciclopedia Universal Ilustrada [Barcelona, n.d.], xxxI, 1461). See also Fortunata y Jacinta, ed. Ortiz Armengol, p. 1015, n. 277.

${ }^{4}$ Roger L. Utt, discussing the windmill as "un símbolo de importancia secundaria," makes a step-by-step analysis of the means by which Galdós establishes this identification. He then goes on to discuss the windmill as a "señal de desventura"; he does not, however, consider the sexual implications of the windmill, nor does he make the connection between the windmill and its function of producing water (" 'El pájaro voló': Observaciones sobre un leitmotif en Fortunata y Jacinta," AGald, 9 [1974], 38-40). 
Maxi is a Romantic idealist confronting the practical age. Because of his terribly underdeveloped body and his extravagant idealism, he has two strikes against him as he tries to adjust to the rough-and-tumble experiences of everyday reality. Like Don Quijote, Maxi has an early encounter with a windmill which he interprets incorrectly, onto which he projects his own feelings, and which hands him a humiliating defeat.

Galdós says concerning the windmill,

lo que más cautivaba la atención del desconsolado muchacho era un motor de viento, sistema Parsons, para noria, que se destacaba sobre altísimo aparato a mayor altura que los tejados del convento y de las casas próximas. El inmenso disco, semejante a una sombrilla japonesa a la cual se hubiera quitado la convexidad, daba vueltas sobre su eje pausada o rápidamente, según la fuerza del aire. La primera vez que Maxi lo observó, movíase el disco con majestuosa lentitud, y era tan hermoso de ver con su coraza de tablitas blancas y rojas, parecida a un plumaje, que tuvo fijos en él los tristes ojos un buen cuarto de hora. (p. 449)

Every morning, Maxi takes a walk out by the convent, to be near Fortunata and to watch the windmill.

Desde que pasaba de la iglesia de Chamberí veía el disco de la noria, y ya no le quitaba los ojos hasta llegar próximo a él. Cuando el motor daba sus vueltas con celeridad, el enamorado, sin saber por qué y obedeciendo a un impulso de su sangre, avivaba el paso. No sabía explicarse por qué oculta relación de las cosas la velocidad de la máquina le decía: "Apresúrate, ven, que hay novedades." Pero luego llegaba y no había novedad ninguna, como no fuera que aquel día soplaba el viento con más fuerza. Desde la tapia de la huerta oíase el rumor blando del volteo del disco, como el que hacen las cometas, y sentíase el crujir del mecanismo que transmite la energía del viento al vástago de la bomba. Otros días le veía quieto, amodorrado, en brazos del aire . . . Sin saber por qué, deteníase el joven; pero luego seguía andando despacio. Hubiera él lanzado al aire el mayor soplo posible de sus pulmones para hacer andar la máquina. Era una tontería, pero no lo podía remediar. El estar parado el motor parecíale señal de desventura. (p. 450)

Thus the windmill, at once aesthetically appealing and menacing, produces in the unfortunate Maxi an ambivalent response. And while his misinterpretation of its symbolic meaning is broadly ironic and tragicomic, his anxiety about the non-functioning windmill is quite appropriate, for Galdós here clearly draws upon the 
age-old association of a pump with masculine sexuality, ${ }^{5}$ preparing the reader for Maxi's eventual inability to perform the physical act of love.

As Maxi is associated with the pumping of water, so Fortunata becomes associated with the receiving of water-and from the very same windmill. During the hottest days of the summer, Fortunata suffers intensely from the heat and needs water to cool and refresh herself. She opens the water faucet completely but "el gran disco que transmitía a la bomba la fuerza del viento, estaba aquel día muy perezoso, moviéndose tan sólo a ratos con indolente majestad; y el aparato, después de gemir un instante como si trabajara de mala gana, quedaba inactivo en medio del silencio del campo" (p. 472). On an even hotter day, Fortunata waits for the water but "el disco de Parsons, inmóvil, miraba a la inmensidad como una pupila cuajada y moribunda" (p. 476). During the evening, the windmill finally begins to turn, "dando dos vueltas y parándose otra vez." Then "no dio después más que media vuelta, y otra vez quieto. El vástago de hierro chilló un instante, y los que estaban junto al estanque oyeron en lo profundo de la bomba una regurgitación tenue. El caño escupió un salivazo de agua, y todo quedó después en la misma quietud chicha y desesperante" (p. 480).

Maxi's impotence after his marriage to Fortunata parallels the windmill's inability to function. "El pobre chico no se encontraba en aptitud de expresarle su desmedido amor de otro modo que por manifestaciones relacionadas exclusivamente con el pensamiento y con el corazón. Palabras ardientes sin eco en ninguna concavidad de la máquina humana, impulsos de cariño propiamente ideales, y de aquí no salía, es decir, no podía salir" (p. 511).

Fortunata consoles Maxi on this occasion, but as time passes she becomes more and more frustrated. Galdós demonstrates this dramatically on the very day when she will become unfaithful to her husband. Again, heat and the presence of water (which does not cool Fortunata) figure prominently in the narrative.

She leaves her house, a location that had been particularly

${ }^{5}$ John S. Farmer and W. E. Henley, Slang and its Analogues (Edinburgh, 1902), v, 320; and David R. Reuben, Everything You Always Wanted to Know about Sex (New York, 1970), p. 8. 
appealing in her premarital planning with Maxi because from its balcony "se alcanzaba a ver un poquito del Depósito de Aguas" (p. 492). Then she strolls inadvertently-but significantly-"junto al Depósito [de Aguas]," where she had sat with Maxi prior to their marriage (p. 439). "Había allí muchos sillares, y sentándose [otra vez] en uno de ellos, empezó a comer dátiles. Siempre que arrojaba un hueso parecía que lanzaba a la inmensidad del pensar general una idea suya, calentita, como se arroja la chispa al montón de paja para que arda" (p. 513). Then she asks herself "¿Pero es verdad que estoy casada yo?" She decides that she is not married in the fullest sense of the word and hurries away to where she knows Juanito Santa Cruz is waiting to renew their sexual relationship (p. 513).

On the night that Maxi finally learns of Fortunata's intimacy with Juanito, Maxi is again seen as associated with the windmill. He has recently consulted a doctor, "el cual le dijo que hubiera sido mejor consultara antes de casarse, pues en tal caso le habría ordenado terminantemente el celibato" (p. 525). And when he finds Fortunata is not at home, he resolves, in great anger, to confront the lovers. Their trysting place-alas!-turns out to be within sight of the windmill. "Al distinguir el motor de la noria que se destacaba sobre la casa de las Micaelas, no pudo reprimir un ahogo de pena que le hizo sollozar. El disco no se movía" (p. 527).

As Maxi awaits the "adúlteros," the windmill is his silent, but by no means neutral, companion: "La noche se venía encima y Maxi deseaba que viniese más aprisa para dejar de ver el disco, que le parecía el ojo del bufón testigo, expresando todo el sarcasmo del mundo. Maldición sacrílega escapóse de sus labios y renegó de que hubieran venido a estar tan cerca su deshonra y el santuario donde le habían dorado la infame píldora de su ilusión. En otros términos: él había ido allí en busca de una hostia, y le habían dado una rueda de molino . . . , y lo peor era que se la había tragado" (pp. 527-28).

Fortunata leaves Maxi at the end of Volume II to become the mistress of Juanito Santa Cruz. With Fortunata sexually satisfied and Maxi under no pressure to perform, we find no further mention of water until Juanito suddenly and cruelly breaks off the relationship. Then Fortunata, completely crushed, wanders about the streets of Madrid in a daze. "Dejándose llevar de sus propios pasos, se encontró sin saber cómo en el centro de la Puerta del Sol. In- 
conscientemente se sentó en el brocal de la fuente y estuvo mirando los espumarajos del agua" (p. 595).

The kindly old colonel, Evaristo Feijoo, rescues Fortunata and in time becomes her protector, installing her in an apartment on Tabernillas Street, while he discreetly lives on San Pedro Street around the corner and across the Puerta de Moros. Fortunata is now enjoying a period of happiness and stability and Galdós begins a paragraph describing the lovers' mutual contentment by stating that "por la solitaria calle de las Aguas se comunicaba brevemente Feijoo con su ídolo" (p. 611).

Water imagery becomes important again when Feijoo's old age forces Fortunata to return to her husband Maxi, with whom she once again becomes sexually frustrated. She tells another character that she saw, by chance, her former lover Juanito near a plumbing shop. "Pues ayer . . . me paré a ver el escaparate de una tienda donde hay tubos y llaves de agua . . . Ni sé por qué me paré allí, pues, ¿qué me importan a mí los tubos?" (p. 716). Even if Fortunata does not know why she is interested in the "tubos," the reader soon perceives their phallic symbolism and the extent of her physical need, for the next day she has a long and very erotic dream which begins with her again, "ante el escaparate de la tienda de tubos . . . jcuánto tubo! Llaves de bronce, grifos, y multitud de cosas para llevar y traer el agua" (p. 720). It is likely that Galdós is providing an additional insight into Fortunata's frustration and Maxi's inadequacy when in the same dream Fortunata notices a sidewalk vendor "que vende los lápices más fuertes del mundo (como que da con ellos tremendos picotazos en la madera sin que se les rompa la punta)" (p. 721).

Some days later Fortunata and Juanito are reunited at the climactic close of Volume III. When Juanito recalls seeing her earlier on the "calle de la Magdalena," Fortunata replies, "Ah sí, ... . [en frente de] la tienda de tubos; muchos tubos." Then Galdós indicates that Fortunata will now have emotional stability and plenty of water as well, for Juanito orders the coachman to drive them to "el Canal" (p. 724), and Galdós says of the carriage in which they are riding, "penetraba en el silencio y en la soledad, como un buque que avanza en alta mar" (p. 725).

${ }^{6}$ This first mention of sea water (from which human life evolved) seems quite appropriate here and contrasts with the fresh, cooling well-water Fortunata had 
This is in complete contrast to her experience with her husband Maxi on their marriage night. Not only was Maxi incapable of controlling and furnishing water, but he was, figuratively speaking, all at sea in the marriage bed-"nadando en las sábanas como si fueran olas." And just before Galdós makes it explicit that Maxi is impotent, he returns to the same imagery, telling us that "[Maxi] había vuelto a nadar entre las agitadas sábanas del lecho y estaba . . . como un niño" (pp. 510-11). ${ }^{7}$

In the final volume of Fortunata y Jacinta Galdós again reminds the reader that the availability of water foreseen by Isabel Cordero de Arnaiz in Volume I has indeed come to pass. This bit of historical realism occurs in two discussions of the various brands of commercial water then popular in Madrid. ${ }^{8}$ In both instances Fortunata has just received a secret message concerning her affair with Juanito Santa Cruz. In the first instance Juanito is abandoning her for the summer; in the second he is returning. At each of these important junctures in the lives of Fortunata and Maxi, Doña Casta Samaniego prattles on to her negativelyaffected listener about the popular brands of commercial drinking water now available in Madrid. On the occasion of the first message, as Fortunata learns that she is being deprived of gratification for the summer (one might say, as she prepares to face a

desired from Maxi (by whom she always knew she would have no children [p. 440]). Now she desires not only sexual satisfaction, but, more importantly, to have a child by Juanito. For the differing aspects of aquatic symbolism and the feminine psyche, see Gaston Bachelard, L'Eau et les rêves (Paris, 1942).

${ }^{7}$ Most critics believe that Maxi was able to have sexual relations (at least intermittently) before his marriage. However his great desire to redeem Fortunata and give her an honorable status is an unconscious "acting-out" of his childhood desires regarding his promiscuous mother. As Joan Connelly Ullman and George H. Allison state, "When they finally marry, the inner reality of Maximiliano's relationship to Fortunata becomes clear. At the deepest level of his unconscious mind, he is bedeviled by the incestuous nature of his sexual desires for his motherwife." His defense against this intolerable situation is impotence, which, of course, causes additional problems. ("Galdós as Psychiatrist in Fortunata y Jacinta," AGald, 9 [1974], 13.)

${ }^{8}$ Galdós confirms the historical realism of these conversations in his column for La Prensa. Speaking of the drinking water, he says, "Hay en Madrid aficionados que . . . la paladean, la catan y distinguen perfectamente las dos o tres clases que tenemos." Then Galdós states his own preference: "La marca Lozoya, digan lo que quieran algunos bebedores muy inteligentes, pero harto apegados a lo antiguo, es la mejor de Madrid y por consiguiente, del mundo" (Shoemaker, Las cartas, p. 468). 
drought), Doña Casta offers her a glass of water and asks her opinion as to which of the brands is the best. It is no surprise to the reader that Fortunata is totally indifferent; she has never been interested in this kind or amount of water. Then, later, when word is received that Juanito has just returned to Madrid and has indicated the time and place where he will see Fortunata on the following day, Doña Casta tries to distract and entertain the mentally-ill Maxi with a "plácida disertación sobre las aguas de Madrid y sobre las propiedades [de cada una de ellas]" (p. 772). This action is as useless and as ironically comic as an earlier attempt by Maxi's family to dispel this cuckolded husband's paranoiac delusion that Fortunata's lover may actually be entering his home. The family tries to reassure Maxi that no one enters his house except the "aguador" (p. 736). ${ }^{9}$

It is in the final volume of the novel also that Maxi reveals an insight into his own mental problems by means of water imagery. As he begins to slip into mental illness, Maxi again identifies with the inability to supply water and reveals to the reader the relationship between his sexual difficulties and his emotional health. He shows clearly how his illness is an escape from, and a solution to, his problem. "Abstraerse, renunciar a todo, anular por completo la vida exterior, y vivir sólo para adentro . . . este es el único bien positivo; lo demás es darle vueltas a una noria de la cual no sale nunca una gota de agua" (p. 735). ${ }^{10}$

Maxi's windmill, then, has several functions in Galdós' masterpiece. First, it mirrors Maxi's emotions. As he approaches his marriage (after being told so often that it is out of the question for him), Maxi refuses to admit, even to himself, his fear of sexual inadequacy. However, he involuntarily projects these feelings onto the windmill, thus allowing the reader to perceive his most deepseated conflicts. The windmill also serves to help focus and define Maxi's masculine self-image. Because the windmill sometimes functions well, Maxi is proud to identify with it. When it does not work, it is merely a temporary failure of energy, which provides

${ }^{9}$ For Galdós' description of the aguador and a statement about his importance, see Shoemaker, Las cartas, p. 469.

${ }^{10}$ Maxi continues to disassociate himself from water as he retreats even further from reality upon learning that Fortunata is pregnant with Juanito's child. He speaks of now having a "sed muy rara, sed espiritual que no se aplaca en fuentes de agua" (p. 735). 
Maxi with an acceptable rationalization. Thus, he does not have to think, as Fortunata does subconsciously, of the more embarrassing symbol of pencils whose points break.

At first circumstantially related to Fortunata, the windmill becomes, in turn, a symbol of Maxi, when it fails to deliver the much-desired water to Fortunata. Thus Galdós develops-out of a mere piece of machinery, a scenic element-a coherent symbolic pattern which helps to define the sexual difficulties that doom the relationship of these two protagonists.

The windmill also helps elevate Maxi to a quixotic level. Many critics have noted the similarities between Don Quijote's and Maxi's desire to create a better world and in their over-idealization of the women they love. Galdós mentions Montesino's cave ( $p$. 580), gives Maxi's brother an "insula" to govern (p. 866), and entitles a chapter "La razón de la sinrazón" (p. 843); thus it is not surprising that he places Maxi in an encounter with a windmill. In nineteenth-century positivistic terms, it is a contemporary mechanism-"sistema Parsons." However, like Don Quijote's seventeenth-century windmill, it provides Maxi with one of the first brushes with harsh reality and helps him progress toward the eventual acceptance of things as they are.

Fortunata is also characterized by the water symbolism and is further differentiated from Maxi by her interest in different aspects of the distribution of water, thus providing a complementary (in this case Fortunata's very personal) feminine point of view.

Galdós, the master of realism, clearly recognized the need to specify the nature of the sexual dysfunction in the tragic MaxiFortunata marriage. He could have chosen simply to explain, early in the novel, what the problem was. To have done so, however, would have been, in the first place, culturally unacceptable in nineteenth-century Spain, and, in the second place, artistically ineffective. Such a frank statement would have limited the possibilities for imaginative elaboration. By locating the early part of the Maxi-Fortunata love story out by the municipal waterworks and then using the availability of water-or lack thereof-to develop the reasons for the failure of their marriage, Galdós achieves a subtle blend of the ironic and tragicomic, while at the same time firmly fixing the historical context. A similar transfiguration of the mundane occurs in the association of Maxi's sexual perfor- 
mance with the activity of the windmill-by means of which Galdós entertains the reader with the type of humor described by Bergson, that derived from the superimposition of the mechanical on human behavior. ${ }^{11}$ Had Galdós chosen to present the problem in essentially clinical terms, the reader would have been denied the pleasure of discovery and the excitement of deciphering the text. By using, instead of straightforward explication, an ancient and archetypal symbolism ${ }^{12}$ to communicate intimate information, Galdós is not only able to identify his character's personal difficulties, but also to evoke for the reader the complexity of human relationships, particularly in their sexual aspect-for which no clinical explanation can ever suffice.

\section{University of Kansas}

\section{Vernon A. Chamberlin}

${ }^{11}$ See Henri Bergson, Le Rire: Essai sur la signification du comique (Paris, 1972), pp. 8-9 et passim.

${ }^{12}$ J. E. Cirlot, A Dictionary of Symbols (New York, 1962), pp. 344-45. García Lorca uses this same symbolism in his well-known drama Yerma. In her article "The Mythic Tragedy of Yerma" (BHS, 49 [1972], 265-78), Patricia Sullivan shows in detail how Lorca's protagonist also needs water and how her husband Juan is unable (and, unlike Maxi, even unwilling) to provide it. Failure to perform the husband's role in this respect, both in Lorca's and Galdós' view, can lead to tragic consequences. Juan is murdered by the frustrated Yerma and Maxi, after being cuckolded, has to spend the rest of his life in a mental asylum. 